\title{
Bending Tests of Large Welded-Steel Box Girders at Different Temperatures
}

\author{
By Ambrose H. Stang and Bernard S. Jaffe
}

\begin{abstract}
Tests were made to determine the effect of constraint caused by geometrical shape and by differences in temperature on the ductile behavior of welded structures. Four large box girders of identical design were fabricated from fully killed steel from the same heat. The box girders were tested as simply supported beams, one girder being tested at each of the following temperatures: $-40^{\circ}, 0^{\circ}, 40^{\circ}$, and $80^{\circ} \mathrm{F}$. The girders tested at $-40^{\circ}$ and $0^{\circ} \mathrm{F}$ broke with a square type of fracture. The other two girders could not be broken with the available equipment, although deflections at midspan of more than 16 inches were induced on a 22 -foot span. The results of these tests are discussed and compared.
\end{abstract}

\section{Introduction}

The failure of several welded-steel ships during the early part of World War II indicated that problems needed to be solved to place the design of welded structures on a sound basis. One of these problems was the effect of constraint caused by geometrical shape and by differences in temperature on ductile behavior. This constraint is believed to result in multidirectional stresses that are "locked-up" in the structure and not caused directly by applied loads. To study this problem, the Structural Steel Research Committee of the Welding Research Council outlined the tests reported in this paper.

The box-girder type of specimen was chosen, because it simulates to a large extent the geometry or shape that was suspected of having caused trouble in ships and other welded structures. Four box girders of identical design and all from one heat at the steel mill were fabricated by the Ingalls Shipbuilding Corporation, Pascagoula, Miss., and tested as beams, simply supported, in the laboratory of the Engineering Mechanics Section, National Bureau of Standards. The steel was a plain low-carbon open-hearth steel (ASTM A-7) fully killed and had good notchtoughness properties at relatively low temperatures. The same sequence of welding was used on each of the girders. Great care was taken to eliminate defects of workmanship during the welding and any possible incipient cracks prior to testing.

One girder was tested at each of the temperatures $-40^{\circ}, 0^{\circ}, 40^{\circ}$, and $80^{\circ} \mathrm{F}$. The girders tested at $-40^{\circ} \mathrm{F}$ and at $0^{\circ} \mathrm{F}$ broke with a square type of fracture. It was impossible to break the other two girders with the available equipment, although deflections at midspan of more than 16 in. were induced during the tests on a $22-\mathrm{ft}$ span.

\section{Box Girders}

\section{Design}

The details of the box girders are shown in figure 1. Each girder consisted of a bottom plate, A, $1 \frac{112}{2}$ in. thick; of two side plates, B1 and B2, each $1 \frac{1}{2}$ in. thick; of a top plate, C, $2 \frac{1}{2}$ in. thick; and of nine diaphragms, D, 1 1 $\frac{1}{2}$ in. thick. The bottom plate, A, was made up of four separate plates-A1, A2, A3, and A4 - with three transverse welds. The diaphragms, $\mathrm{D}$, had snipes, $2 \frac{1}{2}$ in. on a side, at each of the top corners, and smaller ones at the two bottom corners, as well as a central hole 6 in. in diameter. Backing-up bars, $\mathrm{E}$ and $\mathrm{F}$, were used as indicated in figure 1 .

The center of gravity of the cross section of the box girder was approximately $10 \mathrm{in}$. below the top of the girder. The moment of inertia of the section about the neutral surface was about 14,500 in. ${ }^{4}$ 


\section{Fabrication}

The sequence of assembling and welding of the parts of the girder was the same for each of the girders and was as follows:

Plates A1, A2, A3, A4, B1, B2, and D were assembled, fitted, and tack-welded securely by welding one pass on the diaphragm plates, D, to the $\mathrm{A}$ and $\mathrm{B}$ plates. The outside welds of the two longitudinal butt joints joining the $\mathrm{A}$ to the $B$ plates were made; the center diaphragm was welded and welding of the other diaphragms progressed to the ends. The back-up bars, E, were installed on top of the A plates for the later transverse welds between the $\mathrm{A} 1$ and $\mathrm{A} 2$ plates and between the $\mathrm{A} 3$ and $\mathrm{A} 4$ plates. The inside welds of the two longitudinal butt joints between the $\mathrm{A}$ and $\mathrm{B}$ plates were completed, and the snipes at the bottom of the diaphragms were welded. The back-up bars, F, were installed for the longitudinal butt joints between the $\mathrm{B}$ and $\mathrm{C}$ plates, and the strain gages were installed on the inside of the girder. The $\mathrm{C}$ plate was fitted to the $\mathrm{B}$ plates, and the longitudinal butt joints between them were made. The transverse butt joints between the $\mathrm{A} 1$ and $\mathrm{A} 2$, the $\mathrm{A} 3$ and $\mathrm{A} 4$, and the $\mathrm{A} 2$ and A3 plates were made, in that order, to complete the fabrication. The tops of the diaphragms, D, were not welded to the bottom of the $\mathrm{C}$ plate but formed a smooth bearing surface for plate C.

If cracks in the weld metal were revealed at any time by magnafluxing, the metal around the crack was chipped out and rewelded before the subsequent welding pass was made.

The welding sequence, as described above, was designed to set up large shrinkage stresses and produce high values of locked-up stresses.

\section{Coupons}

Extra lengths of the steel plates, A, B1, and B2, were furnished with each girder. Chemical analysis of this material showed percentage contents as follows: Carbon, 0.22 ; manganese, 0.56 ; phos-phorus, 0.015; and sulfur, 0.026.

From each of these lengths two tensile coupons, in the direction of rolling, were machined, six for

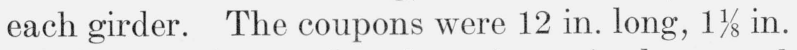
in diameter in a reduced section 9 in. long, and were threaded at both ends to fit the adaptors of the pulling rods.

The tensile tests were made in a horizontal
Amsler testing machine, 100-kip capacity, at the same temperature as that at which the corresponding box girder was tested. For those coupons tested at temperatures below $80^{\circ} \mathrm{F}$, the temperature was maintained by carbon dioxide ice in an insulated box surrounding the specimen. For temperatures of $-40^{\circ} \mathrm{F}$ and of $0^{\circ} \mathrm{F}$, the temperature was measured by means of two copper-constantan thermocouples attached one to each end of the reduced section of the specimen. A mercury thermometer was used for measuring the temperature for tests at $40^{\circ}$ and at $80^{\circ} \mathrm{F}$.

The average results of the coupon tests are given in table 1.

TABLE 1. Average results of tensile tests of coupons

Coupon length parallel to direction of rolling. Each value is the average for the 6 coupons tested at the same temperature

\begin{tabular}{|c|c|c|c|c|c|c|c|}
\hline $\begin{array}{l}\text { Tem- } \\
\text { pera- } \\
\text { ture }\end{array}$ & $\begin{array}{l}\text { Young's } \\
\text { modulus }\end{array}$ & $\begin{array}{l}\text { Pois- } \\
\text { son's } \\
\text { ratio } \\
\text { (elastic) }\end{array}$ & $\begin{array}{c}\text { Propor- } \\
\text { tional } \\
\text { limit } \\
\text { (offiset } \\
3 \times 10^{-5} \text { ) }\end{array}$ & $\begin{array}{l}\text { Yield } \\
\text { strength }\end{array}$ & $\begin{array}{l}\text { Tensile } \\
\text { strength }\end{array}$ & $\begin{array}{l}\text { Elonga- } \\
\text { tion in } \\
4 \text { in. }\end{array}$ & $\begin{array}{l}\text { Reduc- } \\
\text { tion of } \\
\text { area }\end{array}$ \\
\hline${ }^{\circ} \mathrm{F}$ & Kips/in. ${ }^{2}$ & & Kips/in. ${ }^{2}$ & Kips/in. ${ }^{2}$ & Kips $/$ in. ${ }^{2}$ & Percent & Percent \\
\hline-40 & 29,390 & 0.273 & 28.3 & a 33.9 & 68.7 & 39.9 & 56.1 \\
\hline 0 & 30,010 & .280 & 25.8 & a 32.8 & 70.1 & 34.9 & 53.4 \\
\hline+40 & 30,180 & .295 & 22.4 & b 31.4 & 67.7 & 36.6 & 55.7 \\
\hline+80 & 28,580 & .270 & 21.3 & b 30.2 & 65.6 & 37.4 & 53.2 \\
\hline
\end{tabular}

a Yield point by drop-of-beam method.

b Yield strength, 0.002-offset method.

The axial strains and the transverse strains were each determined by means of two $\mathrm{SR}-4$ bonded resistance wire strain gages (A5 or A3) attached at midlength of the specimen. Young's modulus of elasticity and Poisson's ratio in the elastic range, and axial strain-stress and axial strainPoisson's ratio data for plastic strains - were computed from these data. The remainder of the results given in table 1 were computed in the conventional manner.

The values in table 1 show that the proportional limit and yield-strength values decreased as the temperature increased. The other values did not appear to be influenced by the temperature.

Figure 2 shows the average values for the stressstrain and Poisson's ratio-axial-strain relations. The latter values did not appear to vary consistently with temperature. In the stress-strain diagram, the stresses at the knee of the curves decreased as the temperature increased, but on the later ascending portions of the curves, the temperature effects appear to be negligible. 


\section{Tests of Box Girders}

\section{General}

Each box girder was tested as a simple beam, supported on cylindrical bearings on a horizontal span of $22 \mathrm{ft}$, and loaded by two equal loads, $5 \mathrm{ft}$ apart and each $8 \mathrm{ft} 6 \mathrm{in.}$ (102 in.) from the nearer support. Figure 3 shows the box girder in the testing machine for the test at $80^{\circ} \mathrm{F}$.

For tests at temperatures lower than $80^{\circ} \mathrm{F}$, the girder was enclosed in an insulated box and cooled with carbon dioxide ice. To obtain and maintain the low temperature, some of the ice was piled on top of the girder and some placed in the ends of the girder through the holes at the middle of the end diaphragms. Cooling was hastened and regulated by forced circulation through a closed circuit consisting of a blower, pipe to the girder, the girder and a return pipe to the blower as shown in figure 4 . The temperatures were measured by means of six copper-constantan thermocouples near midspan. Three thermocouples were on top of plate $\mathrm{C}$ and three on the bottom of plate A3.

\section{Strain Gages}

The strains at various locations between the lines of load application were measured with SR-4 bonded-resistance wire-strain gages. The locations of the strain gages are shown in figure 5 . Gages 22, 23, 54, and 55 on the bottom edges of the plates $\mathrm{B}$ were single gages, $\mathrm{A} 1$ or $\mathrm{A} 3$. The gages at other locations were rosette gages, $\mathrm{AR}-1$ or AR-2. The nominal gage length was 13/16 in. for all gages.

For the girder tested at $-40^{\circ} \mathrm{F}$, the strains were measured with scanning switches and recorders shown in figure 4 to the left of the girder. Portable strain indicators were used during the other tests.

\section{Deflections}

The deflection of the girder at midspan was measured by the taut-wire mirror-scale method. Deflection readings were generally taken as soon as the load was attained and also at the same load, when the strain readings for that load had been completed.

\section{Method of Test}

The girders were loaded in a number of steps, gradually increasing the load each time but relaxing the load completely between increments of loading. Strains were measured at the various loads and at the zero loads after the load had been removed. For the girder tested at $40^{\circ} \mathrm{F}$ the load was held for a period at 1,200 kips, during which several sets of strain readings were taken, the last set of readings being started $2 \mathrm{hr}$ and $40 \mathrm{~min}$ after the 1,200-kip load had been reached. A set of readings, when the portable strain indicators were being used, took from 15 to $20 \mathrm{~min}$.

Loading was continued until either the girder was broken or until the middle of the girder was nearly in contact with the supporting girder.

\section{Load-Bending Moment Relation}

From the condition of the tests, the bending moment between the points of load application where the strain gages were located was equal to $51 P$-kip-in. if the total load, $P$, is in kips.

\section{Results and Discussion}

\section{Average Axial Strains}

As was to be expected from the general agreement of the stress-strain curves for the coupons at different temperatures, the load-strain relations for the girders were not much affected by differences in temperature. Consequently, in this report it has seemed adequate to treat mainly the load-strain relations at a single temperature, namely $40^{\circ} \mathrm{F}$. The variations for the girder tested at that temperature are similar to those for the other girders tested at other temperatures.

The average strains at a given load for the gages at equal distances from the top of the girder were averaged and have been plotted--for the girder tested at $40^{\circ} \mathrm{F}$-in figures 6 to 17 . In these figures, the inclined dotted line terminated by a horizontal bar represents the load-strain relation as computed by the ordinary beam theory for the location of the gages under consideration and using the average value for Young's modulus for the coupons, as given in table 1 for this girder. The load at the end of this line corresponds to the average proportional limit stress from table 1 .

Tensile strains are plotted to the right. Compressive strains are plotted to the left and indicated as negative. The observed average strains due to the load are shown as open circles. The sets, remaining after the load was removed, are shown as solid circles. 
In general, it may be noted in these figures that the load-axial strain curves practically coincide with the theoretical lines for loads in the lower elastic range. The observed strains at the proportional limit values were generally larger than the computed values. The set values for the greater loads are generally a very large fraction of the corresponding strain-under-load values.

The load-strain curves for gages on the bottom of plate A, figures 12 to 15 , are of especial interest. For the gages not on a weld, figures 12 and 13, the strain was much less in the plastic range for the gages that were opposite a diaphragm, figure 12, than for those not opposite a diaphragm, figure 13 . These strains in the bottom of plate A not on a weld were, in the plastic range, much larger than for the gages that were on a weld, figures 14 and 15. This same phenomenon may be observed during the tensile test of a steel coupon, which has a transverse weld at midlength. For some grades of steel and of weld metal, the weld metal reduces in section very little, after the yielding of the plates commences, whereas there is a visible reduction in section of the adjacent plate material. The permanent sets for the gages on a weld were negative for loads up to more than 1,200 kips. The difference between the load-strain and the load-set curves, at a given load, is, however, very nearly equal at each of these four locations.

The load-axial strain data, obtained during these tests, throws some light on the question as to whether sections plane before loading remain plane after a load is applied. To answer this query, the average axial strains on plates $B$ and $C$ for all the girders have been plotted in figure 18, against the location of the gages on the girder. The solid line is for the 600-kip load (average for four girders). This line cuts the zero-strain line at the computed location of the neutral surface, and all the values are close to this one line. The dash lines have been drawn through the average values for the 1,200-kip load (average for three girders, since the gird er tested at $-40^{\circ} \mathrm{F}$ did not attain this load), and certainly no one line can be drawn through these values so that the strain values at different distances from the top of the girder are close to it. It seems that for these box girders, with diaphragms at various locations along their length, plane sections did not remain plane under loads in the plastic range.

It was suggested that this apparent warping of an initially vertical plane section was due to the timing under which the gage readings were taken and that if the load-while in the plastic rangewere applied for some time before the reading of the gages was started, the sections would be found still plane. The procedure had been to start taking the strain readings about as soon as the load was reached. To study this effect, during the testing of the girder at $40^{\circ} \mathrm{F}$, several sets of readings at a load of 1,200 kips were taken, as has been stated. The average strain values from the readings, started as soon as the load was reached, are plotted in figure 19 against the location on the girder as open circles. As for figure 18 , no one line would represent the data well. The strain values from the readings, started $2 \mathrm{hr}$ and $40 \mathrm{~min}$ after the 1,200-kip load had been reached, are plotted as solid circles in figure 19. They show the commonly observed phenomenon of continued yielding in both tension and compression with a consequent still greater warping. It may be noted that the gages under consideration were not located in the plane of a diaphragm (see fig. 5).

\section{Deflections at Midspan}

The load-deflection curves for the girders are shown in figure 20. The temperature apparently had no significant influence on the deflection. The arrow heads indicate the load and deflection at the failure of the girders, which were tested at $-40^{\circ}$ and at $0^{\circ} \mathrm{F}$. These failures were on the rising portion of the curve. The results indicate that the restraints induced by the welding of the ductile plates were of such magnitude as to result in rather brittle failure for temperatures as high as $0^{\circ} \mathrm{F}$. The temperature of $40^{\circ} \mathrm{F}$ was evidently not low enough to induce failure.

The break in the load-deflection curve, figure 20 , for the girder tested at $80^{\circ} \mathrm{F}$, at a deflection of $11.56 \mathrm{in}$. and a load of 1,530 kips was due to the fact that during the test of this girder, the test was stopped at this deflection when the middle of the girder nearly came in contact with the supporting girder. During this first portion of the test, the supports for the girder were as shown in figure 3 . Since fracture had not occurred, the box girder was taken out of the machine, the cylindrical supports were raised about 6 in. by the blocks shown in figure 21, and the 
girder was again placed in the testing machine. The second portion of the test was made 7 days after the first portion of the test. On reloading, the load-deflection curve between loads of 1,530 and 1,650 kips was not a smooth continuation of the load-deflection curve obtained during the first portion of the test but was much steeper. After the load of 1,650 kips had been attained, the deflection increased with little increase in load until the curve became practically a continuation of that obtained during the first portion of the test. The moving of the girder and the time between the two portions of the test evidently contributed to bringing about some change in the load-deflection relation for this girder, which had already been subjected to plastic yielding.

\section{Maximum Loads}

Table 2 gives a summary of the maximum values obtained at the failure of the girders that broke during the tests at $-40^{\circ}$ and at $0^{\circ} \mathrm{F}$, as well as the maximum values reached during the other two tests when failure did not occur.

The fractured surface of the girder tested at $-40^{\circ} \mathrm{F}$ is shown in figure 22 . The fracture was partly in the weld between the plates A1 and A2 and partly in plate A2. The fracture at midspan of the girder tested at $0^{\circ} \mathrm{F}$ is shown in figure 23 . This fracture took place in plate $A 2$ and not in any portion of a transverse weld.

Figure 21 shows the girder tested at $80^{\circ} \mathrm{F}$ with a deflection of more than $18 \mathrm{in}$.

TABLE 2. Summary of flexural tests of box girders

\begin{tabular}{|c|c|c|c|c|}
\hline $\begin{array}{l}\text { Temper- } \\
\text { ature }\end{array}$ & $\begin{array}{l}\text { Maximum } \\
\text { load }\end{array}$ & $\begin{array}{l}\text { Maximum } \\
\text { moment a }\end{array}$ & $\begin{array}{l}\text { Modulus } \\
\text { of rupture a }\end{array}$ & $\begin{array}{l}\text { Maximum } \\
\text { deflection }\end{array}$ \\
\hline${ }^{\circ} \mathrm{F}$ & Kips & Kip-in. & Kips/in. ${ }^{2}$ & in. \\
\hline-40 & b 1,165 & 59,400 & 63.1 & 2.45 \\
\hline 0 & b 1,476 & 75,300 & 79.9 & 8.83 \\
\hline+40 & - 1,670 & 85,200 & 90.4 & 16.16 \\
\hline+80 & c 1,685 & 85,900 & 91.2 & 18.06 \\
\hline
\end{tabular}

a As computed from the load at failure or from the maximum load that was reached.

b Load at failure.

- Maximum load that was reached. No failure.

\section{Summary}

Bending tests were made on large welded-steel box girders at temperatures of $-40^{\circ}, 0^{\circ}, 40^{\circ}$, and $80^{\circ} \mathrm{F}$. Tensile tests of the material at these temperatures showed that the steel was as ductile at the lowest as at the highest temperature. Due to the constraint induced in the girders by the welding, square types of fracture occurred in the girders tested at $-40^{\circ}$ and at $0^{\circ} \mathrm{F}$ but did not occur in the girders tested at $40^{\circ}$ and at $80^{\circ} \mathrm{F}$.

\section{Appendix}

A fifth box girder, the material of which was a semikilled steel instead of the fully killed steel used in the other four girders, was also tested at room temperature, about $80^{\circ} \mathrm{F}$. This box girder was the same size as the others and differed from the design shown in figure 1 only as follows:

The two diaphragms $\mathrm{D}$ were omitted; the bottom A plate was made of three plates with two transverse welds. Figure 24 shows the details of the bottom view of this girder of semikilled steel. It failed with a square type of fracture after being tested in a manner similar to that for the other four girders.

The load-deflection curve for the girder of semikilled steel is shown in figure 25 by open circles and solid line. The load-deflection curve for the girder of fully killed steel, which was tested at $0^{\circ} \mathrm{F}$, is also shown in this figure, by solid circles and dash line. The results of the tests of these two girders are compared in table 3 .

TABLE 3. Results of flexural tests of two box girders

\begin{tabular}{|c|c|c|}
\hline Girder steel & Semikilled & Fully killed \\
\hline Temperature of test & 80 & 0 \\
\hline Maximum load _. & 1,397 & 1,476 \\
\hline Maximum moment & 71,200 & 75,300 \\
\hline Modulus of rupture & 75.6 & 79.9 \\
\hline Maximum deflection & 8.00 & 8.83 \\
\hline Energy to failure & 8,350 & 10,060 \\
\hline
\end{tabular}

These results show that the girder of fully killed steel tested at $0^{\circ} \mathrm{F}$ was superior in the load properties, as given in table 3 , to the girder of semikilled steel, which was tested at $80^{\circ} \mathrm{F}$.

Washington, April 9, 1948. 


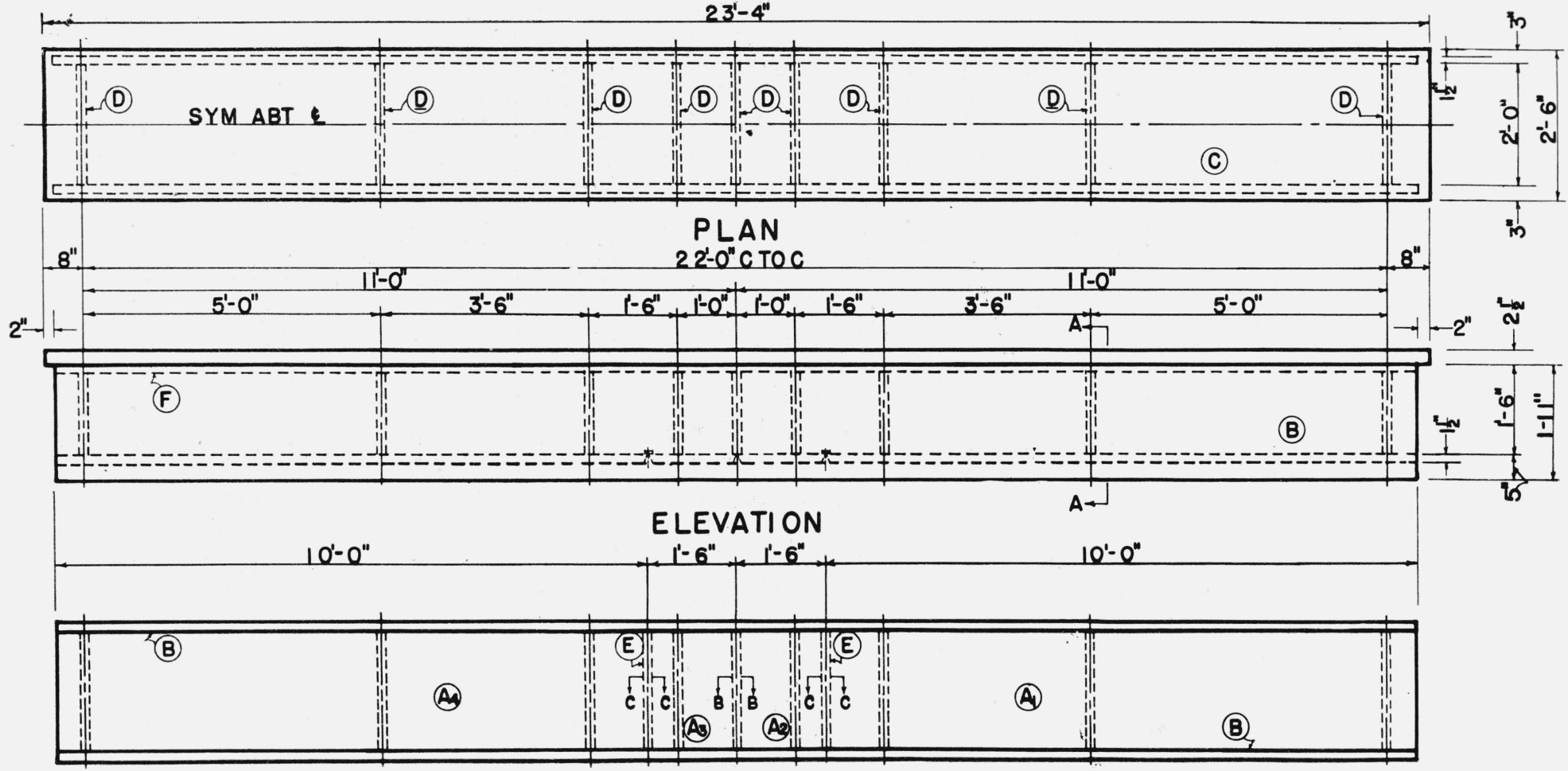

BOTTOM VIEW

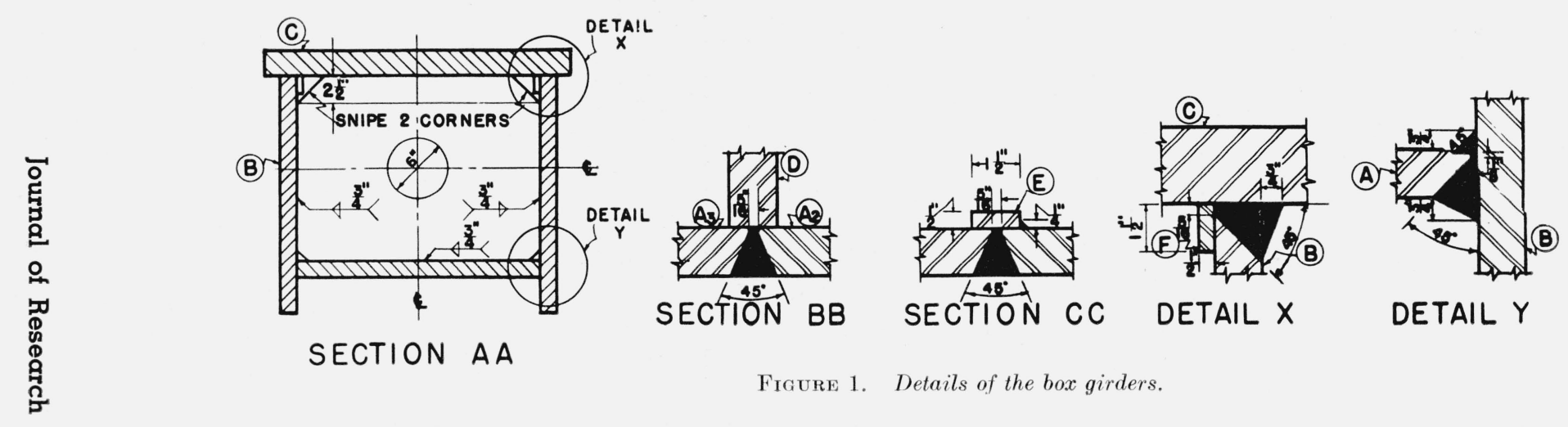



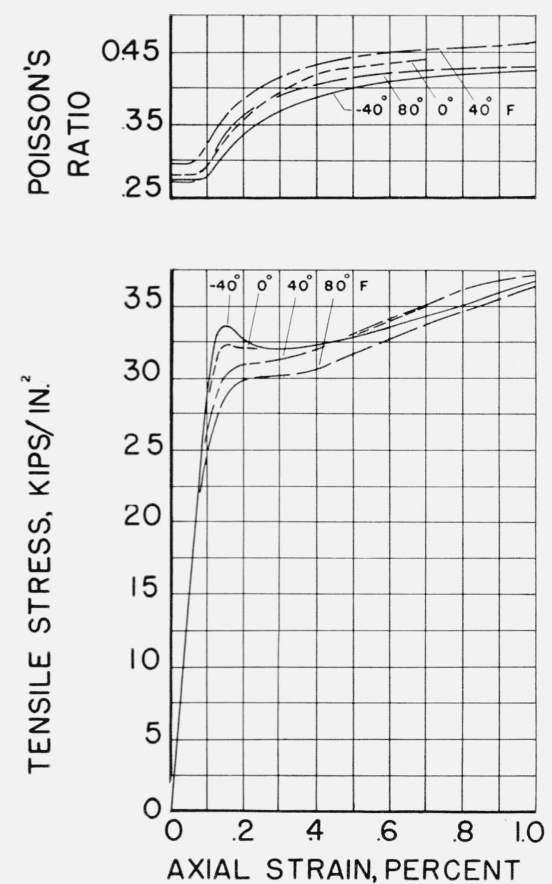

Figure 2. Average results of tensile tests of coupons.

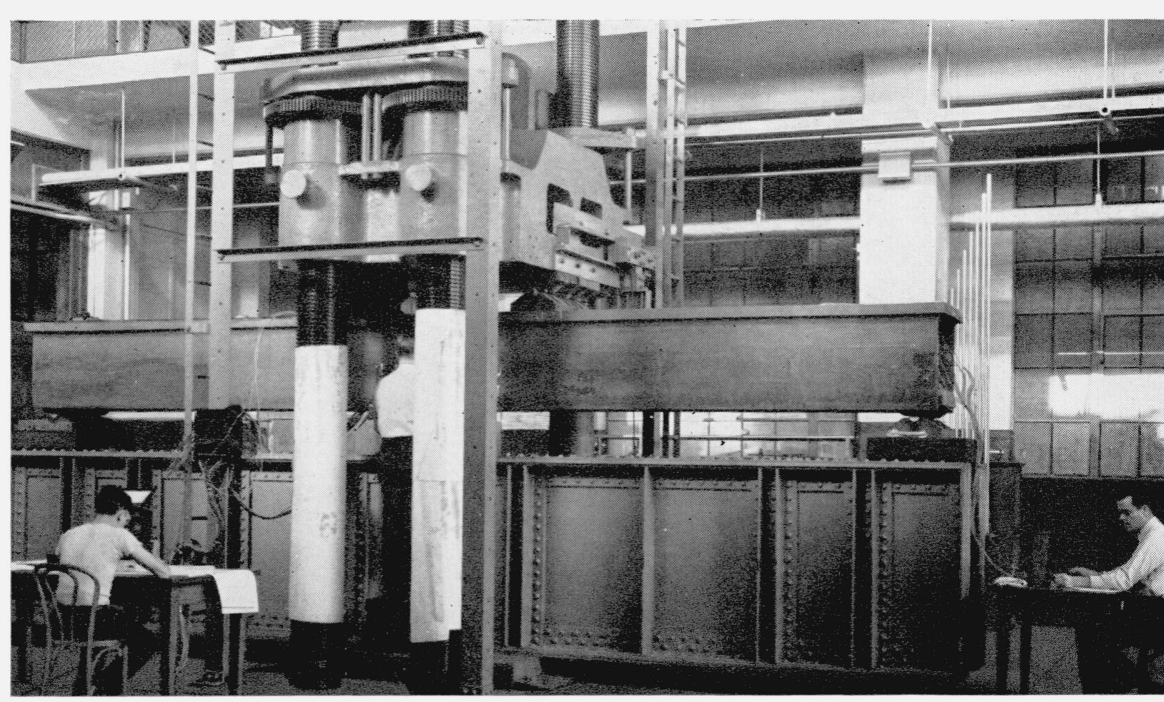

Figure $3 . \quad$ Box girder in the testing machine, at $80^{\circ} \mathrm{F}$, before test.

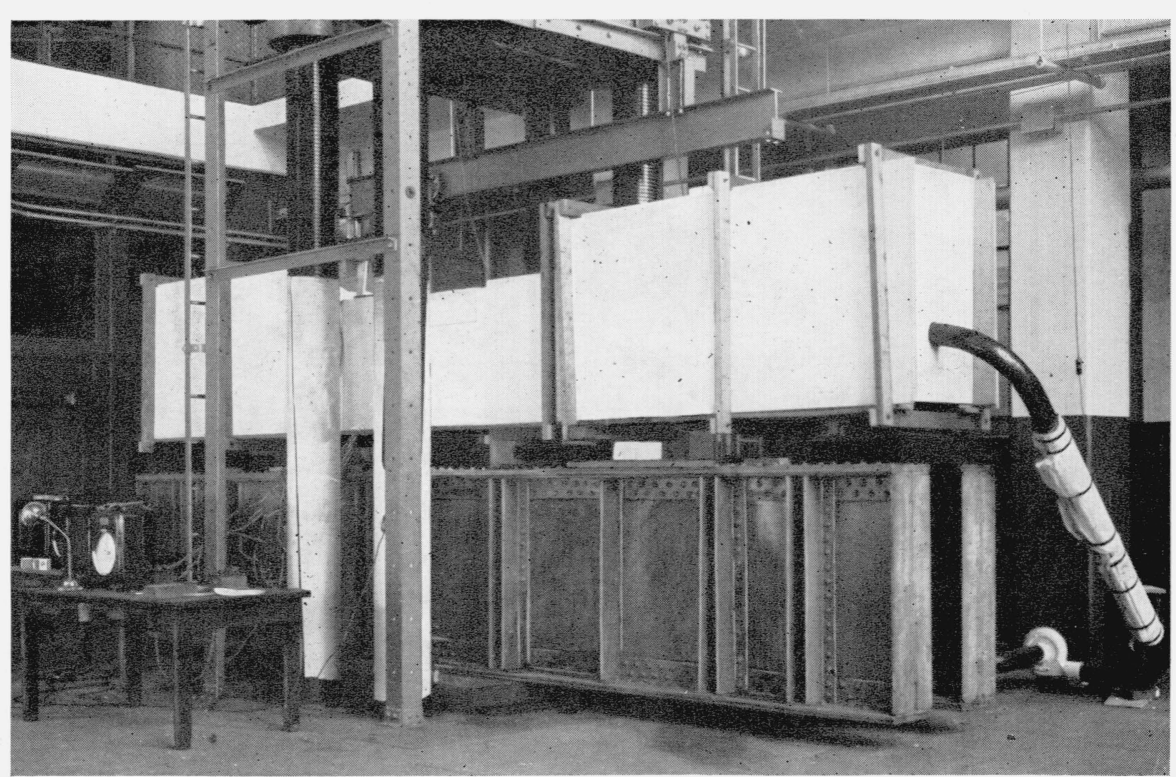

FIGURE 4 Enclosure of the box girder for tests at temperatures below $80^{\circ} \mathrm{F}$.

Note the frost covered blower and pipes of the forced-circulation system. 


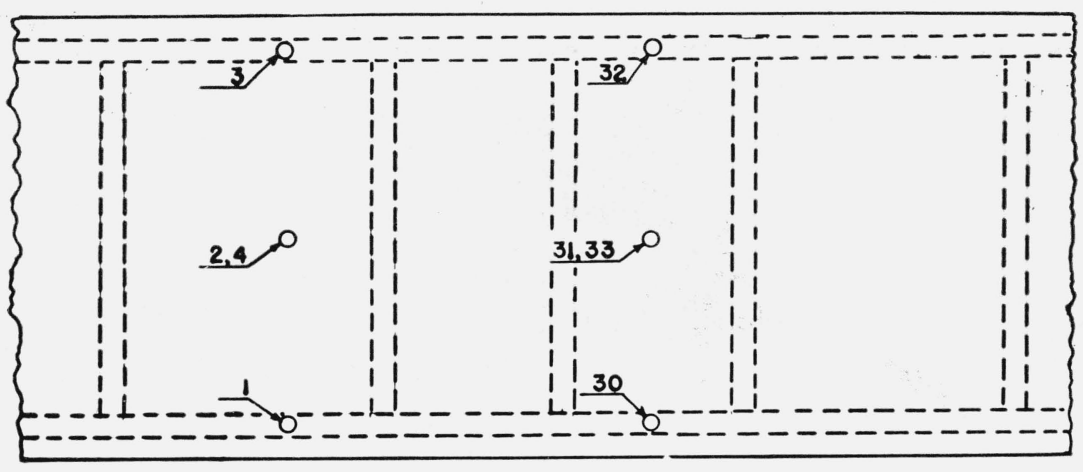

TOP

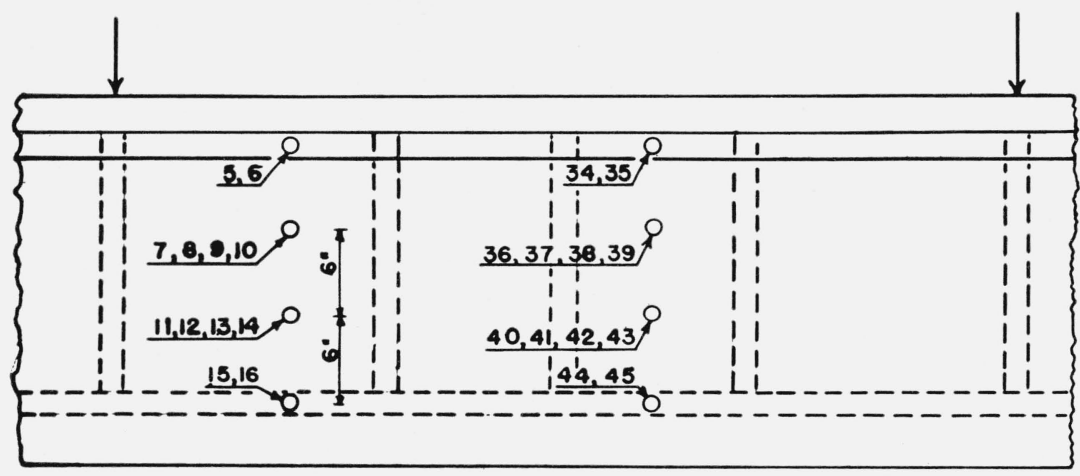

ELEVATION
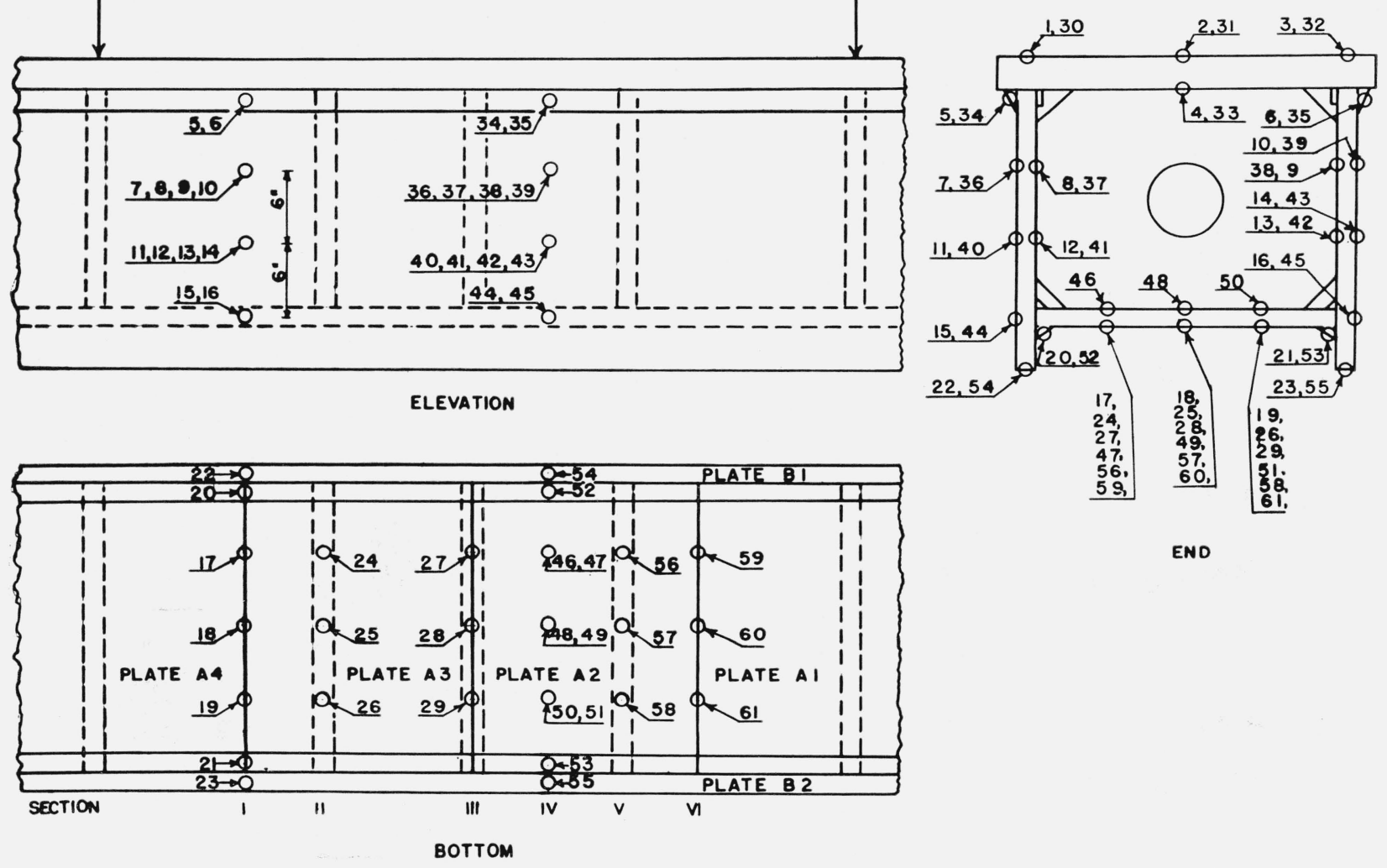

Figure 5. Location of wire-strain gages. 


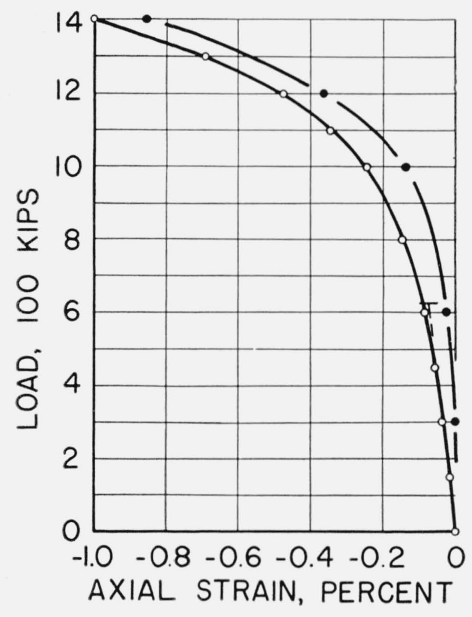

FIgure 6. Average axial strains in the top of plate $C$ of the girder tested at $40^{\circ} \mathrm{F}$ (6 gages).

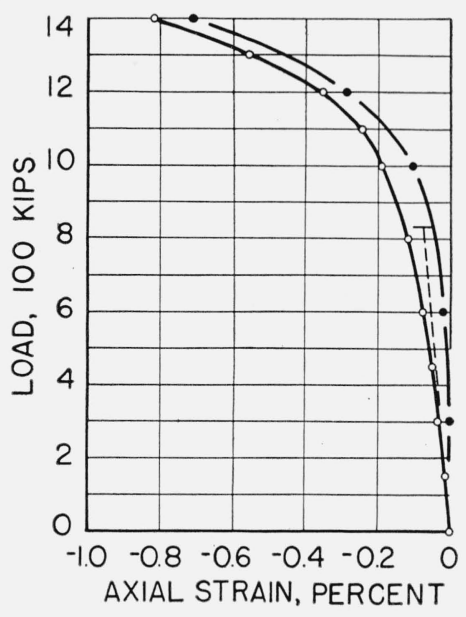

Figure 7. Average axial strains in the bottom of plate $C$ of the girder tested at $40^{\circ} \mathrm{F}$ (2 gages).

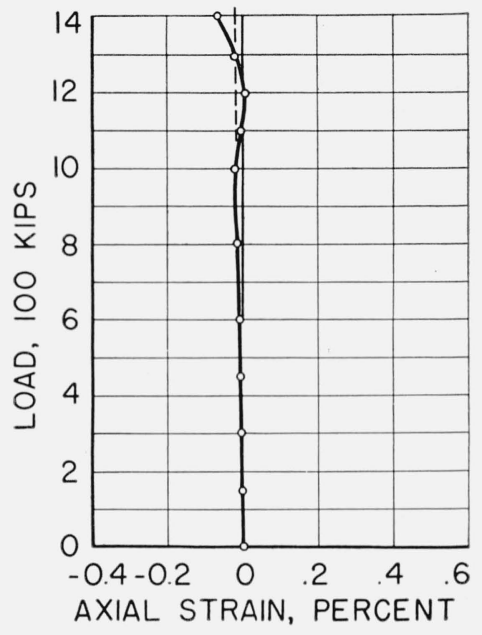

Figure 8. Average axial strains in plates $B$ at $9.25 \mathrm{in}$. from the top of the girder tested at $40^{\circ} \mathrm{F}$ (8 gages).

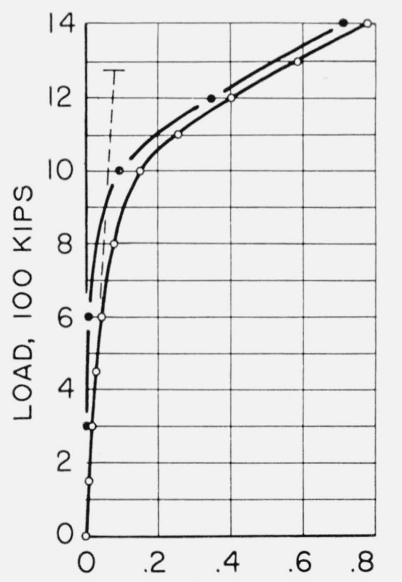

AXIAL STRAIN, PERCENT

Figure 9. Average axial strains in plates $B$ at 15.25 in. from the top of the girder tested at $40^{\circ} F$ (8 gages).

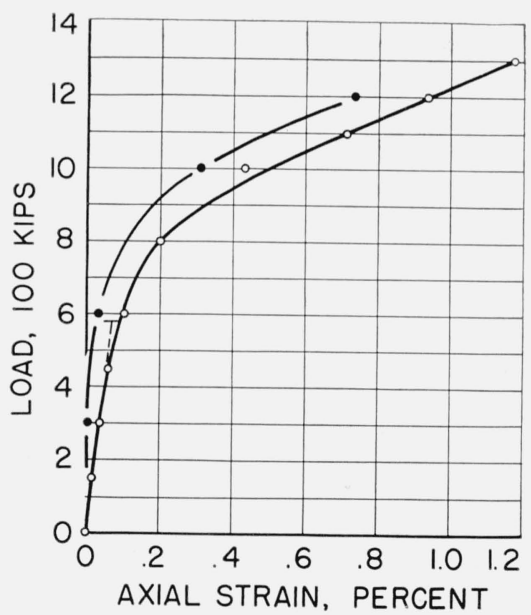

Figure 10. Average axial strains in the top of plate $A$ of the girder tested at $40^{\circ} \mathrm{F}$ (3 gages). 


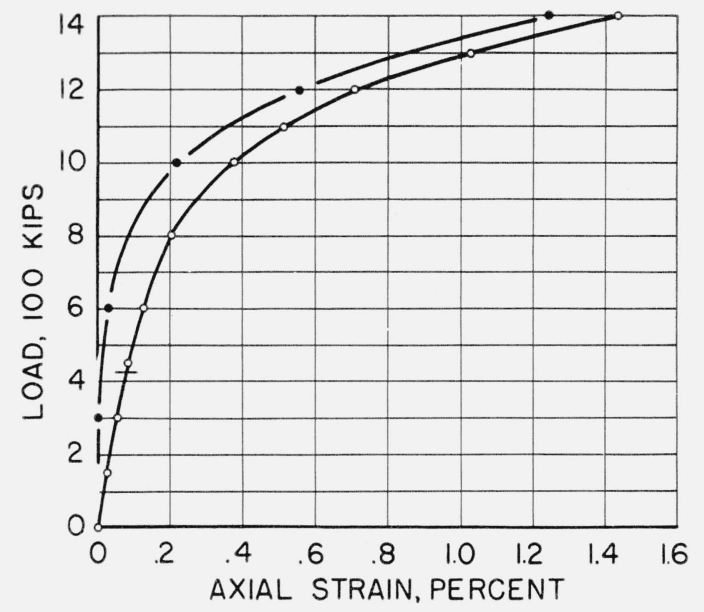

Figure 11. Average axial strains in plates $B$ opposite the midheight of plate $A$ of the girder tested at $40^{\circ} \mathrm{F}$ (4 gages).

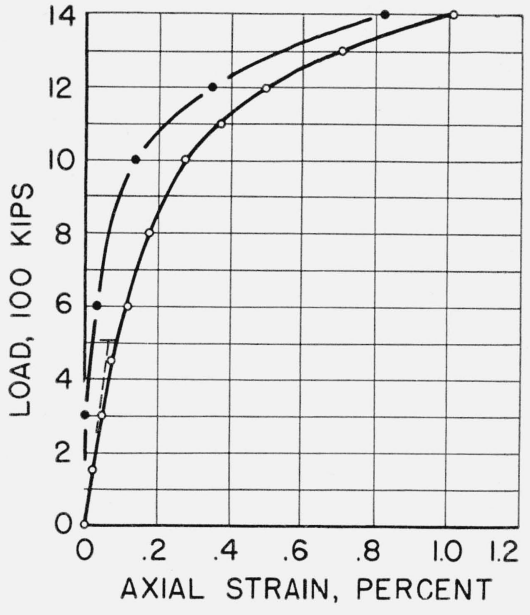

Figure 12. Average axial strains in the bottom of plate $A,-$ not on a weld, opposite a diaphragm - of the girder tested at $40^{\circ} \mathrm{F}$ (6 gages).

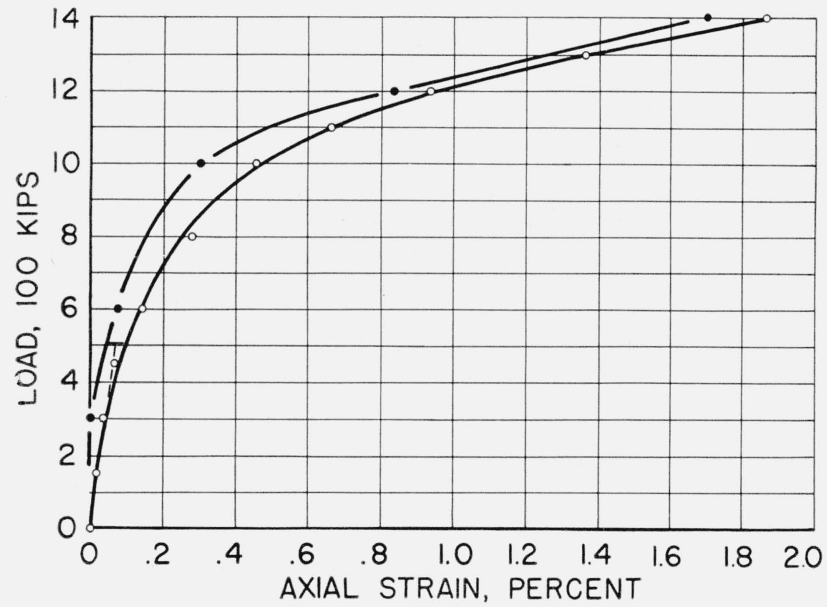

Figure 13. Average axial strains in the bottom of plate A,not on a weld, not opposite a diaphragm - of the girder tested at $40^{\circ} \mathrm{F}$ (3 gages).

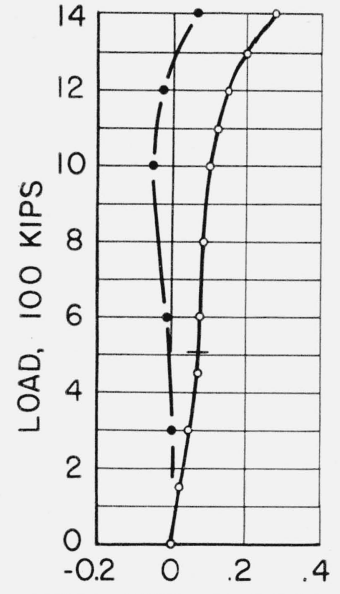

AXIAL STRAIN, PERCENT

Figure 14. Average axial strains in the bottom of plate $A$, 一on a weld, opposite a diaphragm-of the girder tested at $40^{\circ} \mathrm{F}$ (3 gages). 


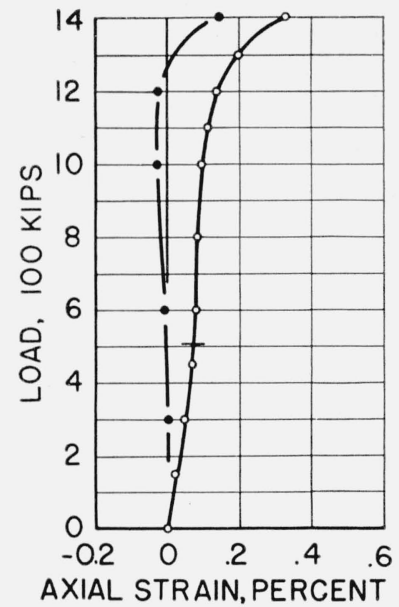

Figure 15. Average axial strains in the bottom of plate A,-on a weld, not opposite a diaphragm-of the girder tested at $40^{\circ} \mathrm{F}$ (6 gages).

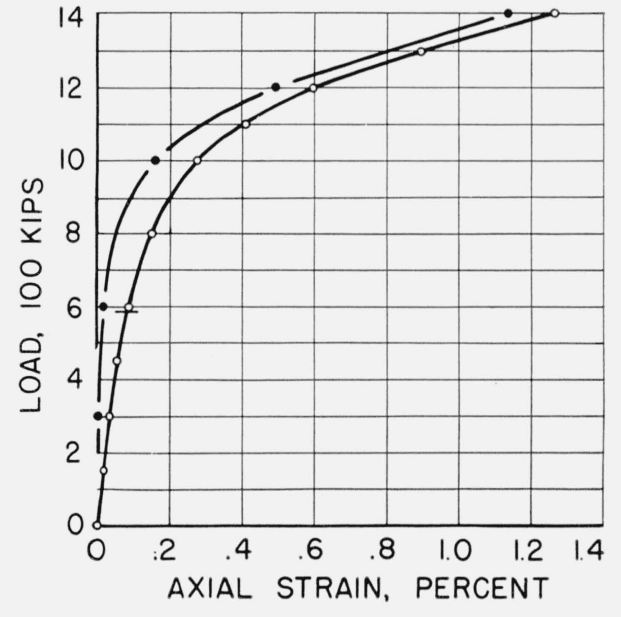

Figure 17. Average axial strains in the bottom edge of the plates $B$ of the girder tested at $40^{\circ} \mathrm{F}$ (4 gages).

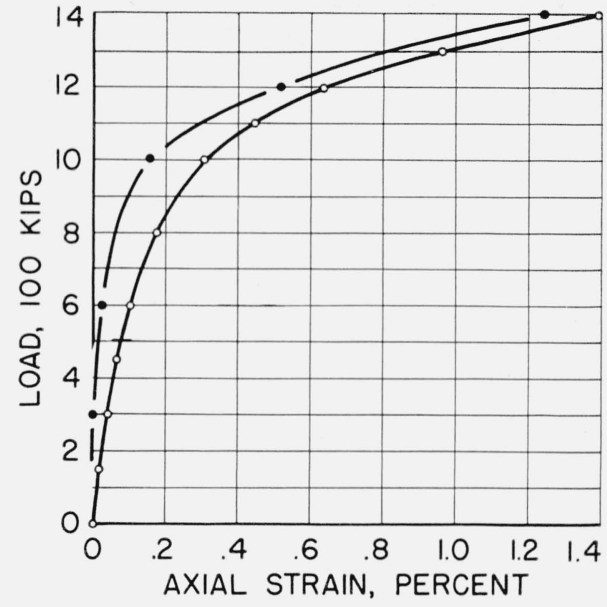

Figure 16. Average axial strains in the welds between plaies $A$ and $B$ of the girder tested at $40^{\circ} \mathrm{F}$ (4 gages).

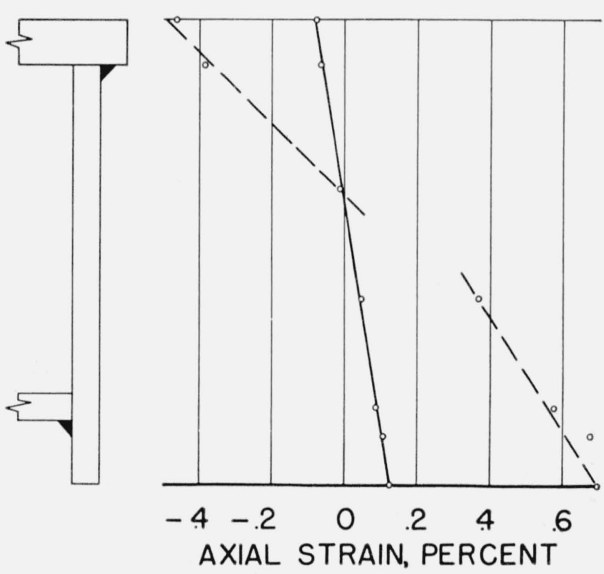

Figure 18. Averaçe axial strains versus gage location, on plates $B$ and $C$ for loads of 600 kips (solid line) and of 1,₹00 kips (dash line). 


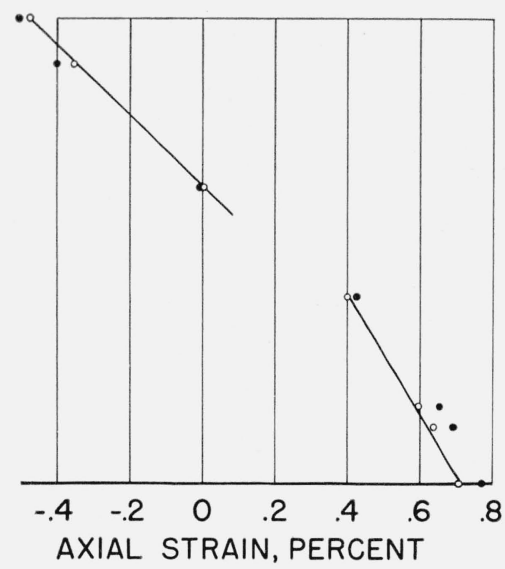

FIgURE 19. Average axial strains versus gage location for a load of 1,200 kips on the girder tested at $40^{\circ} \mathrm{F}$.

Open circles are for readings started as soon as the load was reached; solid circles for readings started $2 \mathrm{hr} 40 \mathrm{~min}$ after the load was reached.

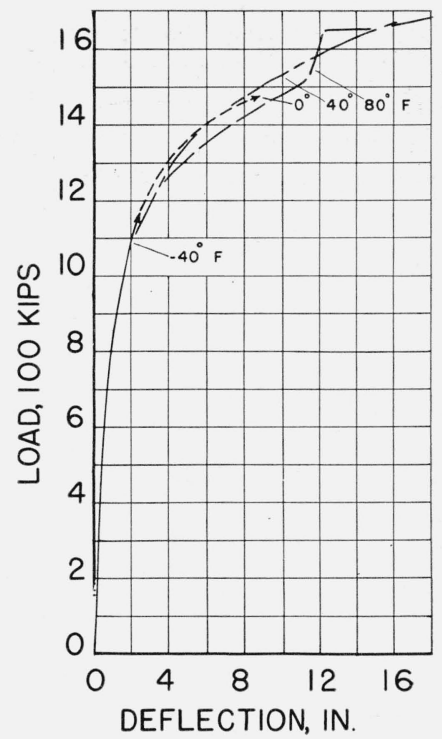

Figure 20. Deflection at midspan for the girders.

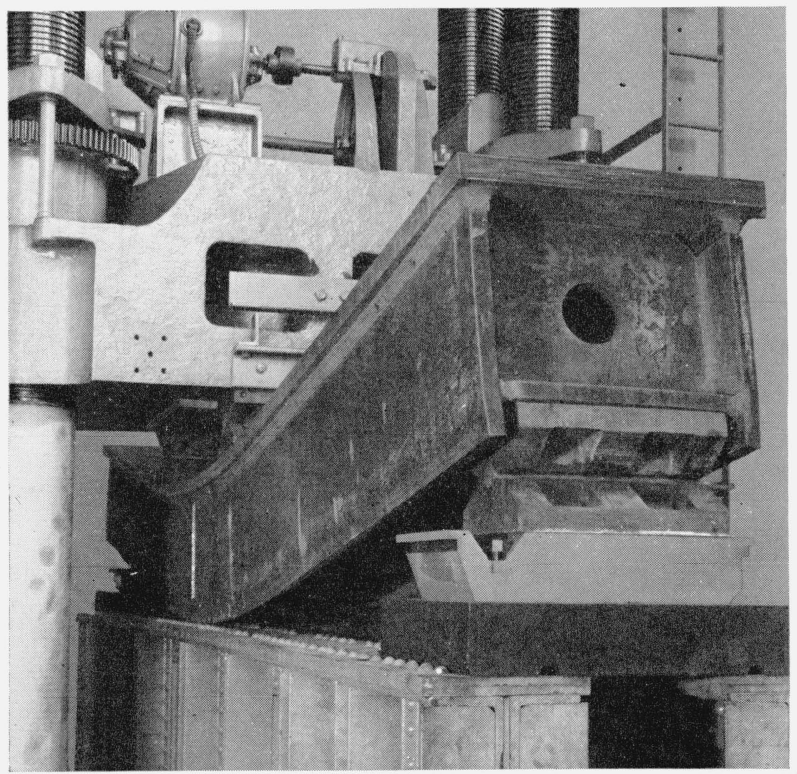

Figure 21. Girder tested at $80^{\circ} \mathrm{F}$ when the deflection was $18.06 \mathrm{in.}$

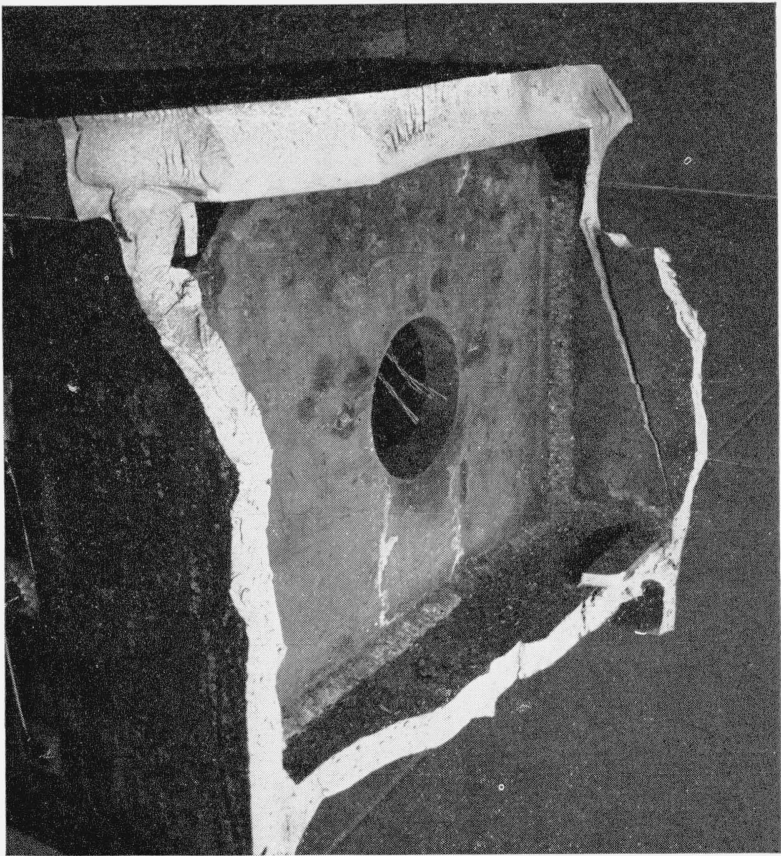

FIgURE 22. Fractured surface of the girder tested at $-40^{\circ} \mathrm{F}$ 


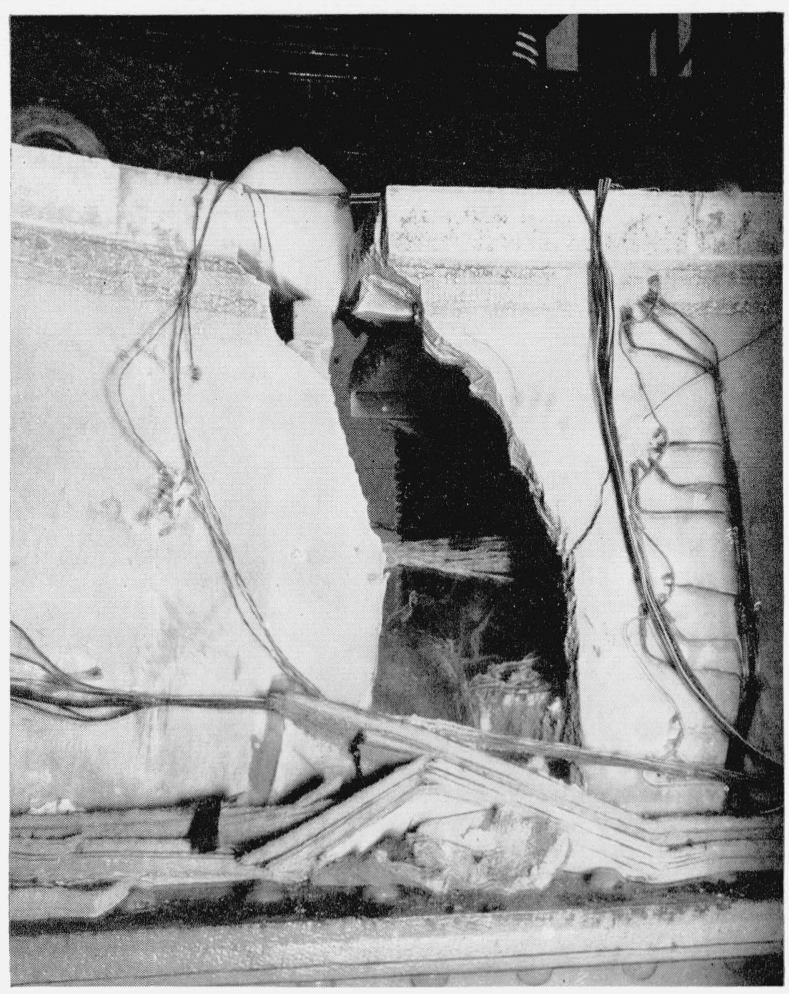

Figure 23. Fracture at midspan of the girder tested at $0^{\circ} \mathrm{F}$.

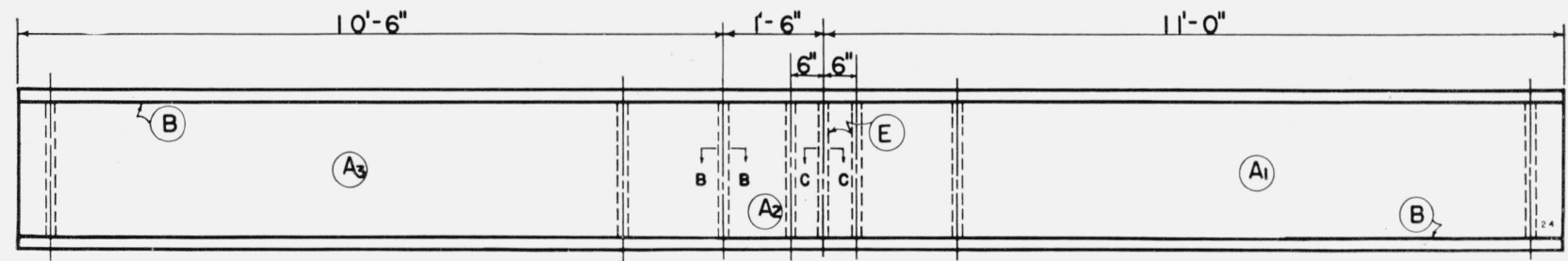

Figure 24. Bottom view of the girder of semiskilled steel.

Other details are shown in figure 1.

Figure 25. Load-deflection curves for two box girders.

Solid line, open circles, a girder of semikilled steel tested at $80^{\circ} \mathrm{F}$. Dash Jine, solid circles, a girder of fully killed steel tested at $0^{\circ} \mathrm{F}$.

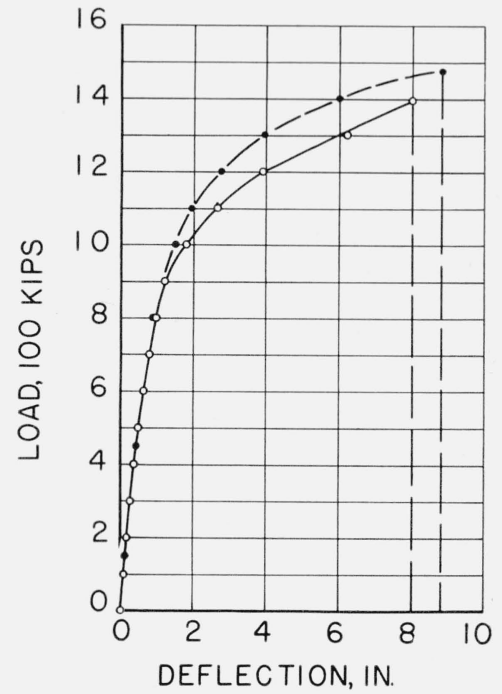

